\title{
ARTUR SCHOPENHAUER JAKO TWÓRCA PRAWDZIWEJ FILOZOFII ZLA W INTERPRETACJI MARIANA ZDZIECHOWSKIEGO
}

\begin{abstract}
Celem opracowania jest próba analizy kolejnej części twórczości Mariana Zdziechowskiego w poszukiwaniu odpowiedzi dotyczącej genezy zła. Rozważania zawarte w artykule rozpoczynają się od krótkiego słowa wstępnego wskazującego na inspiracje, którymi kierował się filozof. Zdaniem polskiego filozofa nie sposób radośnie, po augustyńsku wierzyć, że nie ma zła, że jest ono tylko brakiem bądź czymś drobnym i akcydentalnym. Należy uświadomić sobie, że zło istnieje i że jego byt jest bardzo mocny (o tym w pierwszej części: W poszukiwaniu pierwszej przyczyny zła - filozofia Mariana Zdziechowskiego. Odpowiedzi nie odnalazł również Zdziechowski w analizie zagadnień i interpretacji dzieł Schellinga, Secretana i Sołowjewa (o tym Unde malum? W poszukiwaniu pierwszej przyczyny zła - filozofia Mariana Zdziechowskiego (część 2). Zdaniem Zdziechowskiego największe szanse na odnalezienie odpowiedzi na pytanie dotyczące praprzyczyny zła są teksty Schopenhauera, dzięki któremu, także elementy nauki buddyjskiej zostały przeniesione na grunt europejski. Jest ona wyjątkowo istotna, przede wszystkim dlatego, że porusza najważniejszy jego zdaniem temat: zła i cierpienia w świecie, które było ignorowane przez większość myślicieli europejskich. To Schopenhauer zmusił ich do zainteresowania zagadnieniem zła, przezwyciężył dziewiętnastowieczny optymizm heglowski oraz złamał istniejące kanony myślenia. To właśnie pesymizm - według Zdziechowskiego - który wkradł się do Europy za Schopenhauerem, pozwala prawdziwie uświadomić sobie grozę problemu. Wydaje się, że filozofia Schopenhauera jest dla polskiego myśliciela prawdziwą filozofia zła.
\end{abstract}

Słowa kluczowe: Marian Zdziechowski, filozofia zła, pesymizm, religia, filozofia europejska, Arthur Schopenhauer.

\section{WPROWADZENIE}

Poszukiwania Mariana Zdziechowskiego dotyczące genezy zła, które prowadziły go przez analizę dzieł św. Augustyna ${ }^{2}$, Schellinga, Secretana i Sołowjewa ${ }^{3}$ nie odniosły zamierzonego sukcesu. Polski filozof nie odnalazł niestety odpowiedzi dotyczącej praprzyczyny zła ale refleksja ta przybliżyła go do fascynacji niemieckim pesymizmem w szczególności zaś filozofią Artura Schopenhauera. Co prawda recepcja pesymizmu niemieckiego pojawiła się relatywnie szybko na gruncie polskiej filozofii za sprawą takich

\footnotetext{
${ }^{1}$ Dr Justyna Stecko, Zakład Nauk Humanistycznych, Wydział Zarządzania, Politechnika Rzeszowska, ul. Poznańska 1, 35-084 Rzeszów, tel. 017 8651204, e-mail: jstecko@prz.edu.pl ${ }^{2}$ J. Stecko, W poszukiwaniu pierwszej przyczyny zła-filozofia Mariana Zdziechowskiego (czesść 1), Humanities and Social Sciences, nr 20 (3/2013), ss. 187-192.

${ }^{3}$ J. Stecko, Unde malum? W poszukiwaniu pierwszej przyczyny zła - filozofia Mariana Zdziechowskiego (część 2), Humanities and Social Sciences, nr 20 (4/2013), ss. 185-193.
} 
autorów jak Stefan Pawlicki, Seweryn Smolikowski czy Julian Ochorowicz ${ }^{4}$, ale to dopiero Marian Zdziechowski zaakcentował w szczególny sposób schopenhauerowską filozofię zła. „Zagadnienie czym jest zło, przedtem starannie zasłaniane albo ignorowane w filozofii narodów europejskich, staje nagle w całej grozie. Pogodzić istnienie Boga z istnieniem zła, zespolić chrześcijańską radosną wiarę w Boga, który jest Ojcem niebieskim, z posępną buddyjską afirmacją zła, które tkwi w osnowie bytu oto zasadnicze zadanie dla myśli ludzkiej w wieku XIX"

\section{ARTUR SCHOPENHAUER - FILOZOF KONTROWERSYJNY}

Artur Schopenhauer jest jednym $\mathrm{z}$ tych myślicieli, których teoria nie wynika $\mathrm{z}$ usposobienia autora. $\mathrm{Z}$ jednej strony jest zwolennikiem pogardy dla życia, ale z drugiej jest do niego przywiązany bardziej niż inni. Często także pojawia się pytanie, czy pesymistyczny pogląd na świat tego filozofa jest jedynie efektem niezaspokojonych ambicji i niezadowolenia $\mathrm{z}$ tego co udało mu się osiągnąć w życiu. „Biografia Artura Schopenhauera pełna jest paradoksów i sprzeczności. Rysem głównym jego postaci wydaje się jednak szydercza maska, z jaką się obnosił w poczuciu braku przynależności do swego czasu i dominujących w nim idei. Odpowiadał temu zupełny brak odzewu na jego główne dzieło filozoficzne, co trudno uznać za okoliczność szczególnie sprzyjającą i podbudowującą własny pogląd na świat. Samotność Schopenhauera jest rażąca tym bardziej, że I połowa XIX wieku to w filozofii okres erupcji sił twórczych i wielkiego rozmachu myśli", $\mathrm{Z}$ jednej strony niezwykle twórczy czas dla filozofii z drugiej zaś dominowały idee, które nie były bliskie niemieckiemu filozofowi. Rodził się pooświeceniowy, naukowy obraz świata, charakteryzujący się krytyką religii i demitologizacją świata. Dodatkowo jego negatywna reakcja na spekulatywną metafizykę uprawianą przez Fichtego, Schellinga i Hegla, którzy zdominowali ówczesną filozofię, sprawiła, że był na uboczu głównego nurtu filozoficznego. Dla Safranskiego Schopenhauer jest ,krytykiem nowoczesnego, naukowego obrazu świata, całkowicie zanurzonego $\mathrm{w}$ materii $\mathrm{i}$ wypierającego wszelkie metafizyczne pytania. [...] Zdyskredytowanie spekulatywnego idealizmu absolutnego i jego optymistycznej w wyrazie metafizyki oraz odrzucenie czystego materializmu nauk, tłumaczą według autora odmienny status filozofii Schopenhauera od wszelkich bliższych mu i dalszych współczesnych. Safranski podsumowuje: skończył ze wszystkimi substytutami boskości rozumem w naturze, rozumem historycznym, materializmem, pozytywizmem - w momencie, kiedy tak naprawdę dopiero zaczynano uciekać w te nowe religie wytwarzania",

Filozofia Artura Schopenhauera od początku wzbudzała silne emocje, także negatywne. Kontrowersyjnym wydawała się zdaniem Garewicza krucha konstrukcja:

\footnotetext{
${ }^{4}$ W. Tyburski, Seweryna Smolikowskiego obrona metafizyki i krytyka niemieckiej filozofii pesymizmu, Torun 1995 , s. 35.

${ }^{5}$ M. Zdziechowski, Pesymizm, romantyzm a podstawy chrześcijaństwa, T. I, Warszawa 1993, s.55.

${ }^{6}$ S. Popławski, Żywot filozofa. O książe Rudigera Safrańskiego Schopenhauer. Dzikie czasy filozofii, Miesięcznik ,Znak” nr 648. http://www.miesiecznik.znak.com.pl/10541/zywot-filozofa-o-ksiazce-rudigera-safranskiegoschopenhauer-dzikie-czasy-filozofii

${ }^{7}$ Por. R. Safrański, Schopenhauer. Dzikie czasy filozofii, Warszawa 2008.

${ }^{8}$ S. Popławski, op. cit.
} 
„,cztery lata po śmierci Schopenhauera Rudolf Haym, pierwszy kompetentny krytyk całości opublikowanych przez niego dzieł, odkrył w systemie sprzeczności tak jaskrawe, że w konkluzji odmówił Schopenhauerowi w ogóle miejsca w filozofii [...]"9. Jednak kontrowersyjność jego teorii i oryginalność syntezy elementów pochodzących z systemów filozoficzno - religijnych Indii, stała się jednocześnie jej atutem. Dodatkowo fakt, że nie poddawał się modzie i obiegowym tendencjom miał spory wpływ na jego późniejszą popularność.

\section{ARTUR SCHOPENHAUER TWÓRCA FILOZOFII ZLA W INTERPRETACJI MARIANA ZDZIECHOWSKIEGO}

Wydaje się, że najważniejszym elementem w dorobku Schopenhauera jest traktat z 1819 roku „Świat jako wola i przedstawienie”, zaś pozostałe teksty to jedynie uzupełnienie tej koncepcji. Sam Schopenhauer mało skromnie tak analizuje swoje dokonania: „W ciągu ostatnich pięćdziesięciu lat trzy rzeczy wpłynęły na nas: filozofia Kanta, nieporównane postępy nauk przyrodniczych [...], wreszcie zaznajomienie się z literaturą sanskrycką, $\mathrm{z}$ braminizmem i buddyzmem, tymi dwiema najstarszymi i najbardziej rozpowszechnionymi religiami ludzkości”' ${ }^{\prime \prime}$. U Schopenhauera pierwiastek pesymizmu zaznaczył się jeszcze silniej niż u myślicieli indyjskich. Być może miała na to wpływ epoka w której żył. Epoka, jak nazywa ją Marian Zdziechowski, płytkiego optymizmu, skierowanego na praktyczną stronę życia, która gotowa była usprawiedliwić wszystkie okropieństwa jako objaw idei absolutnej. Na to zaś Schopenhauer zgodzić się nie mógł.

Pierwotnie Marian Zdziechowski zrezygnował z pesymistycznej interpretacji dzieł Schopenhauera, wskazując nirwanę jako drogę wyzwolenia z cierpienia ${ }^{11}$. Jednak pisząc już „Pesymizm, romantyzm a podstawy chrześcijaństwa”, zmodyfikował swoją ocenę. Według polskiego filozofa osobą odpowiedzialną za przybliżenie inspiracji buddyjskich europejskim myślicielom, jest właśnie Schopenhauer. Zdziechowski jego główną zaletę widzi w tym, że porusza najważniejszy jego zdaniem temat: zagadnienie cierpienia oraz zła, które było ignorowane przez większość myślicieli europejskich.

Zdaniem Zdziechowskiego właśnie tacy filozofowie potrzebni są chrześcijaństwu, niezbędny jest pesymizm, który może pomóc przygotować odrodzenie religijne Europy, który pozwali prawdziwie uświadomić sobie grozę problemu i da narzędzia aby z nim walczyć. Filozofia Schopenhauera pomoże wyleczyć się z płytkiego optymizmu. „Wobec kryjówek, gdzie chowa się nędza przed obojętną ciekawością gawiedzi, wobec szpitali, lazaretów, klinik chirurgicznych, wobec lochów więziennych i rusztowań, gdzie tracą skazańców, wobec usłanych trupami pobojowisk, na których rozlegają się jęki konających w strasznych męczarniach - słowem, wobec ogromu cierpienia niezmiennie związanego z przyrodzonym porządkiem rzeczy, i wobec ogromu nieprawości i złości człowieka, który tę katownię, jaką jest ziemia, wysila się uczynić jeszcze straszniejszą dla bliźniego swojego" "12, nie sposób być optymista. Jednak kłopotem dla Zdziechowskiego, mocno zaangażowanego w myśl chrześcijańską, były poglądy niemieckiego filozofa dalekie od

\footnotetext{
${ }^{9}$ J. Garewicz, Schopenhauer, Warszawa 2000, s. 14.

${ }^{10}$ A. Schopenhauer, Świat jako wola i przedstawienie, tłum. J. Garewicz, Wydawnictwo Naukowe PWN, Warszawa 1994, t. I, s.12.

${ }^{11}$ Por. J. Skoczyński, Niemiecka filozofia życia, [w:] idem, Wartość pesymizmu, Kraków 1994, s. 59.

${ }^{12}$ M. Zdziechowski, op. cit., t. I, s. 187.
} 
Boga myśli teistycznej. Dla Schopenhauera Absolutem była wola, którą rozumie jako siłę motywującą do działania. Nie jest to jednak siła o charakterze zbawiennym, to raczej fizyczny pęd, który sprowadza podmiot do biologii.

Wola życia - tak ją określił Schopenhauer - jest ślepa, bezrozumna, jest ciągłą dążnością. Nieświadoma, irracjonalna moc nieustannie nakierowuje się na jakiś przedmiot i to jest przyczyną trwania świata. Świat to wola, która nigdy nie będąc nasyconą, jest źródłem ustawicznego cierpienia, a ,istnienie, na jakie tu skazani jesteśmy, jest najstraszniejszym ze wszystkich możliwych istnień i żywym obrazem absolutnego zła"13. Realizacji woli nieustannie towarzyszy cierpienie, od którego nie sposób się uwolnić, ponieważ jest ono związane $\mathrm{z}$ ciaggłymi pragnieniami człowieka ${ }^{14}$. Istotą człowieka jest wola, nie zaś myśl, jak twierdził Kartezjusz. Dla Schopenhauera nie cogito ergo sum, lecz volo ergo sum bardziej trafia w istotę człowieczeństwa. Jednak pragnąć znaczy cierpieć; każde pragnienie, mając swe źródło w niezadowoleniu z istniejącej sytuacji - jest cierpieniem, gdy zaś zostanie zaspokojone, natychmiast rodzi się nowe i tak popadamy w kolejne cierpienie.

Zdaniem Schopenhauera świat to piekło, ludzie zaś są zarówno dręczonymi, jak i dręczycielami. Wszyscy, będąc wytworami woli życia, która jest złem, jesteśmy zarazem jej wspólnikami; czyli jesteśmy źli już w istocie swojej, z natury. Jednym z wyrazów zła jest egoizm człowieka, samolubstwo, z którym możemy walczyć. Przeciwieństwem zaś litość, która będzie stanowić podstawę etyki Schopenhauera. Jednak nie wystarczy poprzestać na walce $z$ egoizmem, ponieważ to tylko zewnętrzny przejaw zła. Trzeba zło zniszczyć w samym zarodku, w sobie należy zabić wolę życia. Bardzo pomocna w tej trudnej walce może być świadomość własnej śmiertelności i przemijalności. Pozwoli nam ona jeszcze bardziej uświadomić sobie, że byt to ciagłe stawanie się, ciaggły proces, przemijalność. „Życie wszelkie we Wszechświecie powstaje jakby po to, aby przejść i zniknąć; więc wszystko jest znikomością"15.

Pesymizm wynikający $\mathrm{z}$ doświadczenia cierpienia, do którego przyczynia się nienasycona wola, wydaje się, że można przezwyciężyć. W tym miejscu jawią się przynajmniej dwa wyjścia. W pierwszym przypadku należałoby zanegować wolę jednostkową, pozbyć się wszelkich pragnień i pożądań. Doprowadzić do etapu samonegacji, który pozwala dotrzeć do stanu nirwany, czyli swoistego zawieszenia między życiem a śmiercią. Osiagnięcie stanu nirwany miało być uwarunkowane wyzbyciem się wszystkich pragnień, które wikłają człowieka w świat zewnętrzny. Stan ten miał zapewnić całkowity spokój, ponieważ wyzbycie się wszelkich namiętności, miało dać ucieczkę od pragnień związanych z doznaniami świata zewnętrznego.. Jednak negacja woli życia nie jest tożsama ze śmiercią, lecz z ascezą ${ }^{16}$. Pierwszym wymaganiem ascezy jest czystość, dalej ubóstwo, wreszcie brak sprzeciwu wobec zła, które jest wymierzone przeciwko mojej osobie. „[...] albowiem radosne przyjmowanie wszelkiej szkody, wszelkiej krzywdy daje mi pewność, że już się wyzwoliłem z przywiązania do życia"17. Ideał ascezy jest możliwy jednak tylko dla wybranych. Ze względu na postulowaną ogromną trudność osiągnięcia stanu nirwany Schopenhauer zaproponował drugi sposób

\footnotetext{
${ }^{13}$ Ibidem, s. 137.

${ }^{14}$ Por. ibidem, s. 125.

15 Ibidem, s. 138.

${ }^{16}$ Por. J. Skoczyński, Pesymizm filozoficzny Mariana Zdziechowskiego, Kraków 1983, s. 39.

${ }^{17}$ M. Zdziechowski, op. cit., s.177-178.
} 
ucieczki od cierpienia - proponował kontemplację estetyczną. Piękno, ze względu na swoją szczególną siłę może dawać wybawienie. Sposobem na trud ludzkiej egzystencji miał być zachwyt nad pięknem obecnym w naturze i sztuce oraz współtworzenie go. Kontemplacja sztuki umożliwia poznanie czyste, ponieważ piękno to kategoria niezależna od woli i chęci. Zdaniem Zdziechowskiego, nie był to jednak pomysł trafny, ponieważ rozwiązanie to nie usuwa zła, a ma jedynie łagodzić cierpienie. Wobec realnego zła nie jest to żadne wyjście ${ }^{18}$.

Spore wątpliwości nasuwa próba utożsamienia filozofii Schopenhauera z koncepcją chrześcijańską. Co prawda Marian Zdziechowski jest zdania, że myśl indyjska nie stoi w opozycji do chrześcijaństwa, a wskazując na zbieżne elementy próbuje udowodnić bliskość tych koncepcji. Zarówno w myśli chrześcijańskiej jak i w buddyzmie pojawia się kategoria ascezy, której celem jest osiagnnięcie doskonalszego bytu - dla buddystów nirwany, dla chrześcijan zaś nieba. Schopenhauer pojmował nirwanę raczej jako nadbyt niż niebyt, więc bardzo blisko chrześcijańskiej koncepcji. Jednak najważniejszym zagadnieniem według Zdziechowskiego w każdej religii jest relacja człowieka $\mathrm{Z}$ Absolutem. Buddyzm - jak wiadomo - ignorował Boga, stąd Schopenhauer również porzuca jego ideę, mimo to Zdziechowski widzi dużą zbieżność z rozwiązaniami w myśli chrześcijańskiej. Buddyści oddawali cześć Buddzie podobną jak chrześcijanie Chrystusowi, a nawet stworzono pośrednika między Buddą a ludźmi - Adibuddę stanowiącego przejście od ziemskiego doświadczenia cierpienia do błogosławionej nirwany. Według Zdziechowskiego Schopenhauer poszedł o krok dalej. Uznał, że poza wolą życia, którą trzeba stłumić, jest jeszcze taka wola, którą należy uczcić. Przedstawiał ją jako genialnego mistrza, który dba o swoje dzieło i wykańcza je z wielką dokładnością. Zdziechowski sugeruje więc, że wolę tę powinien nazwać Bogiem i czcić ${ }^{19}$, tego jednak Schopenhauer nie zrobił. W interpretacji Zdziechowskiego udałoby się nawet uzgodnić myśl chrześcijańską dotyczącą grzechu pierworodnego, ponieważ logicznym wydaje się wnioskowanie: że skoro jesteśmy tworami złej woli życia, to jesteśmy naznaczeni złem, niedoskonałością. Od takiego wniosku jest już tylko krok do stwierdzenia grzechu pierworodnego.

Artur Schopenhauer nie widzi niestety żadnych zbieżności, co więcej traktuje buddyzm jako antytezę chrześcijaństwa. Najbardziej oburzającym jest niemożliwość, pogodzenia dobroci Boga $\mathrm{z}$ otaczającym nas w świecie złem; jeśli dodamy do tych wątpliwości pytanie o korelację wszechwiedzy Stwórcy z wolną wolą człowieka, dochodzimy zdaniem myśliciela do absurdu. Wyższość buddyzmu dostrzegał także w tym, że zauważony został świat zwierząt, który w koncepcji chrześcijańskiej jest praktycznie pomijany. „Trzeba więc raz na zawsze - pisze - porzucić wszelkie twierdzenie o wyższości etyki chrześcijańskiej [...]. I ta chrześcijańska $\mathrm{z}$ imienia, a zhańbiona swojem podłem okrucieństwem wobec zwierzęcia Europa ma czoło posyłać misjonarzy swoich, aby nieśli braminom i buddystom światło prawdziwej wiary! Wszak misjonarz - trupożerca jest zbrodniarzem w oczach Indianina i budzić w nim innego uczucia jak wstręt nie może. To samo, jak gdyby od ludożerców przybył do nas jakiś ich kapłan i począł nauczać nas i wysławiać dobrodziejstwa kanibalizmu"20.

\footnotetext{
${ }^{18}$ Por. J. Krasicki, op. cit., s. 174.

${ }^{19}$ Por. ibidem, s. 191-196.

${ }^{20}$ Ibidem, s. 191-192.
} 
Zdziechowskiemu, który był świadomy niechęci jaką Schopenhauer darzył chrześcijaństwo, nie przeszkadza wnioskować, że ,między nauką Schopenhauera a metafizyką chrześcijańską jest równoległość" ${ }^{21}$, a różnice wskazują jedynie na wyższość myśli chrześcijańskiej ${ }^{22}$.

\section{ZAKOŃCZENIE}

Zdziechowski po analizie i interpretacji wielu dzieł, także koncepcji Artura Schopenhauera wnioskuje, że nie uda się wyjaśnić genezy zła. Wszelkie próby ostatecznych rozstrzygnięć natrafiają na trudności. Część koncepcji ogranicza człowieka na co nie chciał się zgodzić, inne zaś organiczną Boga, na co zgodzić się nie mógł. Być może pytanie dotyczące źródeł zła pozostanie bez odpowiedzi. Marian Zdziechowski jednak nie poddaje się. Problematyka zła była dla niego jednym z najważniejszych problemów filozoficznych, dlatego po odrzuceniu możliwości uzasadnienia metafizycznego zajął się analizą możliwości przezwyciężenia zła oraz ukazywaniem określonych skutków działania złego.

\section{LITERATURA}

[1] Garewicz J., Schopenhauer, Warszawa 2000.

[2] Popławski S., Żywot filozofa. O ksiażce Rudigera Safrańskiego Schopenhauer. Dzikie czasy filozofii, Miesięcznik ,Znak” nr 648: http://www.miesiecznik.znak.com.pl/10541/zywot-filozofa-o-ksiazcerudigera-safranskiego-schopenhauer-dzikie-czasy-filozofii

[3] Safrański R., Schopenhauer. Dzikie czasy filozofii, Warszawa 2008.

[4] Schopenhauer A., Świat jako wola $i$ przedstawienie, tłum. J. Garewicz, Wydawnictwo Naukowe PWN, Warszawa 1994, t. I.

[5] Skoczyński J., Niemiecka filozofia życia, [w:] idem, Wartość pesymizmu, Kraków 1994.

[6] Skoczyński J., Pesymizm filozoficzny Mariana Zdziechowskiego, Kraków 1983.

[7] Stecko J., Unde malum? W poszukiwaniu pierwszej przyczyny zła - filozofia Mariana Zdziechowskiego (część 2), Humanities and Social Sciences, nr 20 (4/2013).

[8] Stecko J., W poszukiwaniu pierwszej przyczyny zła - filozofia Mariana Zdziechowskiego (czesść 1), Humanities and Social Sciences, nr 20 (3/2013).

[9] Tyburski W., Seweryna Smolikowskiego obrona metafizyki i krytyka niemieckiej filozofii pesymizmu, Toruń 1995.

[10]Zdziechowski M., Pesymizm, romantyzm a podstawy chrześcijaństwa, T. I, Warszawa 1993.

\footnotetext{
${ }^{21}$ Ibidem, s. 197.

${ }^{22}$ Schopenhauer uważał, że wolę życia trzeba zanegować, unicestwić, chrześcijaństwo zaś każe ją przeobrazić.
} 


\section{ARTHUR SCHOPENHAUER AS THE CREATOR OF THE TRUE PHILOSOPHY OF EVIL IN THE INTERPRETATION OF THE MARIAN ZDZIECHOWSKI}

The aim of this paper is to analyze the next part of the work of Marian Zdziechowski in the search of the answers concerning the origins of evil. The considerations contained in the article begins with a brief foreword indicating the inspiration that the philosopher guided. According to the Polish philosopher it is impossible, in an Augustynian way to believe that there is no evil, that it is only the lack of something, or something small and accidental. One should realize that evil exists and that its existence is very strong (about this in the first part: In search of the first cause of evil - Marian Zdziechowski' philosophy ${ }^{23}$. Zdziechowski did not also find the answer to this question in the analysis of issues and interpretation of the works of Schelling, Secret and Sołowjew (about that in Unde malum? In search of the first cause of evil - Marian Zdziechowski's philosophy (part 2). According to Zdziechowski the best chance of finding the answer to the question about the root causes of evil are the texts by Schopenhauer, through which, the elements of the Buddhist teachings have been moved into Europe. it is extremely important, primarily because in his opinion it touches the most important topic: the evil and suffering in the world, which was ignored by most of the thinkers of Europe. It was Schopenhauer who forced them to get interested in the issue of evil, he overcame the nineteenth century Hegelian optimism and broke the existing canons of thought. It is the pessimism - according to Zdziechowski - which has crept into Europe thanks to Schopenhauer, which truly allows to realize the horror of the problem. It seems that Schopenhauer's philosophy is for the Polish thinker the philosophy of true evil.

Keywords: Marian Zdziechowski, the philosophy of evil, pessimism, Schopenhauer, religion, European philosophy.

DOI:10.7862/rz.2014.hss.30

Przesłano do redakcji: grudzień 2013

Przyjęto do druku: lipiec 2014

\footnotetext{
${ }^{23}$ J. Stecko, W poszukiwaniu pierwszej przyczyny zła - filozofia Mariana Zdziechowskiego (część1), Humanities and Social Sciences, nr 20 (3/2013), ss. 187-192.
} 